\title{
Immunostimulatory effect of sweet potato peel-based plant mixture on RAW264.7 macrophages
}

\author{
In-Seon Jeong ${ }^{1}$, Eun-Hye Kim ${ }^{2}$, Seung Man Park ${ }^{1}$, Mi Ja Chung ${ }^{2 *}$ \\ ${ }^{1}$ Hyundai F\&B Co., Ltd., Gwangju 61200, Korea \\ ${ }^{2}$ Gwangju University, Department of Food Science and Nutrition, Gwangju 61743, Korea

\section{고구마껍질 주원료인 식물 혼합물의 RAW264.7 대식세포에서 면역활성 증진효과} \\ 정인선 ${ }^{1} \cdot$ 김은혜 ${ }^{2} \cdot$ 박승만 $^{1} \cdot$ 정미자 $^{2 *}$ \\ 1농업회사법인 현대에프엔비(주), ${ }^{2}$ 광주대학교 식품영양학과
}

\begin{abstract}
This study aimed to investigate the immunostimulatory effect of a sweet potato peel-based plant mixture, including Platycodon grandiflorum, Codonopsis lanceolata and com silk, on RAW264.7 macrophages. We tested the immunostimulatory effect of 12 plant extracts, individually, in terms of nitric oxide (NO) production in RAW264.7 macrophages. NO production of Platycodon grandiflorum, Codonopsis lanceolata, and corn silk extracts (PG, CL, CS) in RAW264.7 macrophages was significantly higher than that of other plant extracts $(p<0.05)$. The cytotoxicity and production of NO and cytokines by PG, CL, CS, and weet potato peel extract (SP) in RAW264.7 macrophages were determined. The production of tumor necrosis factor (TNF)- $a$, interleukin (IL)-1 $\beta$, and IL-6 in PG, CL or CS-treated RAW264.7 macrophages was significantly higher than that of SP-treated ones $(p<0.05)$. Immunostimulatory effect of the extract from plant mixture containing Platycodon grandiflorum, Codonopsis lanceolata, com silk, and sweet potato peel in the ratio 1:1:0.5:3 (w/w) was significantly higher than that of SP extract alone, and was similar or higher than that of PG, CL, and CS, on RAW264.7 macrophages $(p<0.05)$. Therefore, the extract from plant mixture may be considered as a potential candidate for the development of functional food materials for enhancing immune activity.
\end{abstract}

Key words : cytokines, immunostimulatory effect, nitric oxide, RAW264.7 macrophages, sweet potato peel

\section{서 론}

100 세 시대를 맞이하여 사람들은 건강하게 오래 사는 것을 바라고 있지만 서구화된 식생활, 스트레스 등에 의해 다양한 만성질환의 발병률이 증가하고 있다(1). 이러한 질 병들의 예방 및 개선을 위해 면역 활성 증진 효과를 가진 기능성 식품소재 및 다양한 제품 개발에 대한 연구들이

*Corresponding author. E-mail : mijachung@gwangju.ac.kr Phone : 82-62-670-2049

Received 30 September 2019; Revised 28 October 2019; Accepted 29 October 2019.

Copyright (c) The Korean Society of Food Preservation. All rights reserved.
진행되고 있다(2,3). 면역반응은 인체 내의 자기방어체계로 외부로부터 유입된 병원성 항원으로부터 우리 몸을 보호하 기 위한 수단으로 작용 한다. 대식세포는 inducible nitric oxide synthase(iNOS)에 의해 유도된 면역조절인자인 산화 질소(nitric oxide; $\mathrm{NO}$ ), 종양괴사인자(tumor necrosis factor; TNF-a), 인터루킨(interleukin-6; IL-6), IL-1 $\beta$ 등을 분비하여 면역체계를 유지한다(4)

도라지(Platycodon grandiflorum)는 초롱꽃과에 속하는 다년생 식물로 예부터 식품뿐만 아니라 해열, 진통, 진정작 용과 항염증 효과를 가진 약재로서 사용되어져 왔다(5,6). 항암효과와 간기능 개선에도 효과가 있는 triterpenoid계 사 포닌과 섬유질을 포함하고 있으며 $(7,8)$, 도라지의 주요 사 포닌은 platycodin $\mathrm{A}, \mathrm{C}$ 및 $\mathrm{D}$ 와 platycoside $\mathrm{A}, \mathrm{B}, \mathrm{C}, \mathrm{D}$ 및 
E가 있다고 알려져 있다(9).

더덕(Codonopsis lanceolata)의 초롱꽃과에 속하는 다년 생 식물로 구이, 무침, 장아찌 등 식품으로 이용되고 있고, 더덕의 주요성분은 saponin, flavonoid 및 inulin 등으로 밝혀 진 바 있다(10). 더덕의 효과에 관한 연구로는 면역력 증가, 혈청지질의 감소 및 더덕 부위별 세포벽 물질의 항산화 효과가 보고되어졌고 거담, 해열, 배농, 강장제 등 질병치료 목적으로도 사용되어져 오고 있으며(11-16), 흰쥐의 간과 혈액에 더덕껍질과 더덕육질을 섭취시킨 후 생체 내 항산화 방어 시스템을 확인한 결과, glutathione peroxidase(GPx)와 glutathione reductase(GR)의 활성이 증가되었다(17).

시중에서 가장 흔하게 접하는 식용작물 중 하나인 옥수 수(Zea mays L.)는 전분가공, 음료, 통조림 등으로 가공되고 있다(18). 옥수수의 부산물인 옥수수수염은 일부 옥수수수 염 차 등의 원료로 사용되고 있지만 폐기되는 양이 더 많다 $(19,20)$. 옥수수수염은 황색-담갈색을 띄며 한국, 중국, 일본 등 동남아시아 지역에서 이뇨제와 신장질환 치료 목적으로 쓰여진 기록이 많다 $(21,22)$. 특히, 옥수수수염에는 apimaysin, methoxyamaysin과 maysin 등이 존재하는데 이 중, maysin 은 종양 세포주를 사멸시키는 항암효과 및 라디칼 소거작용 등이 보고되었다(23).

고구마(Ipomoea batatas L.)는 식량자원으로 이용되고 있 고 강한 항산화 효과가 있는 페놀화합물은 고구마 껍질부분 에 많이 함유되어 있어, 고구마 속 부분보다 껍질부분이 항산화 활성이 더 우수한 것으로 알려져 있다(24). 고구마의 껍질 부분의 주요물질은 caffeic acid와 chlorogenic acid이며 강한 항산화 효과가 있고(24), caffeic acid와 caffeic acid phenethyl ester의 면역 활성에 관한 연구가 보고된 바 있다 $(25,26)$. 고구마 말랭이 등 고구마 가공식품은 대부분 고구 마 껍질을 제거한 후 사용하고 있어 고구마 가공과정에서 발생하는 고구마 껍질을 이용한 다양한 가공식품 개발의 중요성이 대두되고 있다. 이러한 다양한 이유 때문에 대부 분의 소비자에게 적용할 수 있는 고구마 껍질을 주성분으로 하여 소비자의 입맛에 맞고, 면역력증진 효과가 강화된 최 적 배합비를 가진 식물혼합물 개발이 절실히 요구되고 있는 상황이다.

따라서 이와 같은 목적을 달성하기 위해 본 연구에서는 문헌조사를 통하여 면역 활성 증진 효과가 알려졌거나 식용 및 약용으로 이용되고 있는 도라지(Platycodon grandiflorum), 더덕(Codonopsis lanceolata), 잔대(Adenophora triphylla), 옥수수수염(Corn silk), 당귀(Angelica gigas), 가시오가피 (Acanthopanax senticosus), 황기(Astragalus membranaceus), 천궁(Cnidium officinale), 백출(Atractylodes macrocephala Koidzumi), 숙지황(Rehmanniae Radix Preparat), 작약 (Paeoniae radix) 및 마늘(Allium sativum L.)을 천연소재들 로 선택하였다. 이들 소재들의 물 추출물들의 면역 활성 증진 효과를 NO 생성량 증가로 알아보았다. 이들 결과들을
근거하여 $\mathrm{NO}$ 생성량 증가가 높은 4 개의 천연소재를 발굴하 였다. 발굴된 4 개의 천연소재에 대해 NO 생성량뿐만 아니 라 TNF-a, IL-1B 그리고 IL-6 생성량으로 면역 활성 효과를 알아보았다. 주식과 간식으로 사용되고 있는 고구마 껍질 의 면역 활성 증진 효과를 알아본 후 부작용을 최소한 한 천연소재 혼합물 개발을 위해 도라지, 더덕 및 옥수수수염 을 선택하였다. 도라지 및 더덕은 예부터 약용뿐만 아니라 나물 등 다양한 반찬으로 사용되고 있어 부작용에 대한 위험성이 없고 옥수수수염도 시중에 옥수수수염 차가 판매 되고 있다. 본 연구의 목적은 폐기되고 있는 고구마껍질을 활용하는 것이므로 고구마껍질 포함 4개의 천연소재를 이 용하여 5 종류의 배합비를 만들었다. 그리고 5 종류 배합비 의 면역 활성 증진 효과를 알아보았다. 이들 혼합물에 함유 된 단일 추출물들과 혼합물들의 면역활성을 서로 비교하여 최종적으로 최적 배합비를 가진 식물혼합물을 개발하였다.

\section{재료 및 방법}

\section{재료 및 추출물 제조}

본 연구에 사용한 도라지(Platycodon grandiflorum)와 더 덕(Codonopsis lanceolata)은 강원도 횡성 약재시장 (Hoengseong, Korea)에서 건조한 것으로 2017년 10월에 구 입하였고, 잔대(Adenophora triphylla), 옥수수수염(Corn silk), 당귀(Angelica gigas), 가시오가피(Acanthopanax senticosus), 황기(Astragalus membranaceus), 천궁 (Cnidium officinale), 백출(Atractylodes macrocephala Koidzumi), 숙지황(Rehmanniae Radix Preparat) 그리고 작약(Paeoniae radix)은 한약재시장(Seoul, Korea)에서 2017년 10월에 건조한 것으로 구입하여 사용하였으며, 마 늘(Allium sativum L.)과 고구마(sweet potato)는 광주광역시 에 위치한 대형마트에서 한국산으로 2017년 10월에 구입하 여 마늘은 슬라이스로 잘랐고 고구마는 고구마껍질(sweet potato peel)만 얻은 후 $40^{\circ} \mathrm{C}$ 에서 건조 후 본 연구에 사용하였 다. 분쇄한 분말 시료는 중량의 10 배인 증류수를 넣어 $60^{\circ} \mathrm{C}$ shaking incubator(JSSI-100C, JSR, Seoul, Korea)에서 24시 간 추출하였다. 추출한 것을 Whatman filter paper No. 2(Whatman International Ltd., Springfield Mill, Kent, UK)를 사용하여 여과하였다. 여과한 추출물은 감압농축기 (N-1200, Eyela, Tokyo, Japan)를 사용하여 추출 용매를 제거 한 후 동결건조기(Clean vac 8, Hanil, Incheon, Korea)로 동결건조 한 분말은 $-20^{\circ} \mathrm{C}$ 에 보관하였다. 도라지 추출물 (PG), 더덕 추출물 (CL), 잔대 추출물(AT), 옥수수수염 추출 물(CS), 당귀 추출물(AG), 가시오가피 추출물(AS), 황기 추출물 $(\mathrm{AM})$, 천궁 추출물 $(\mathrm{CO})$, 백출 추출물( $\mathrm{AR})$, 숙지황 추출물(RR), 작약 추출물(PR), 마늘 추출물(ALS) 및 고구마 껍질 추출물(SP) 동결건조 분말을 본 실험에 사용하였다. 


\section{최적배합비 개발을 위한 혼합물 제조}

도라지, 더덕, 옥수수수염 및 고구마 껍질 건조 분말 (PGP, CLP, CSP 그리고 SPP)을 1:1:1:0.5 비율(w/w)로 혼합 한 후 상기 방법과 동일하게 추출, 여과, 농축 및 동결건조 한 동결건조 분말을 Mixture 1이라 하였고, 고구마 껍질 건조 분말 비율을 증가한 5가지 mixtures를 만들었다. 즉 본 연구에 사용된 Mixture 1-5의 PGP, CLP, CSP 그리고 $\mathrm{SPP}$ 의 비율은 Table 1 과 같다.

Table 1. The ratio of mixtures containing Platycodon grandiflorum, Codonopsis lanceolata, corn silk and sweet potato peel

\begin{tabular}{cc}
\hline Mixtures & Mixture ratio $(w / w)$ \\
\hline Mixture 1 & PGP $^{1)}: \mathrm{CLP}^{2)}: \mathrm{CSP}^{3)}: \mathrm{SPP}^{4)}=1: 1: 0.5: 1$ \\
Mixture 2 & PGP $:$ CLP $:$ CSP $:$ SPP $=1: 1: 0.5: 2$ \\
Mixture 3 & PGP $:$ CLP $:$ CSP $:$ SPP $=1: 1: 0.5: 3$ \\
Mixture 4 & PGP $:$ CLP $:$ CSP $:$ SPP $=1: 1: 0.5: 4$ \\
Mixture 5 & PGP $:$ CLP $:$ CSP $:$ SPP $=1: 1: 0.5: 5$ \\
\hline
\end{tabular}

${ }^{1)}$ PGP : Platycodon grandifforum powder.

${ }^{2)}$ CLP : Codonopsis lanceolata powder.

${ }^{3} \mathrm{CSP}$ : corn silk powder.

${ }^{4}$ SPP : sweet potato peel powder.

\section{세포 배양 및 처리}

마우스 대식세포주 RAW264.7 cells는 American Type Culture Collection(ATCC, Manassas, VA, USA)에서 구입하 여 사용하였고, $10 \%$ 비활성화 우태아 혈청(fetal bovine serum, FBS; Gibco-BRL, Carlsbad, CA, USA) 및 $1 \%$ penicillin와 streptomycin(PEST; WelGene Co., Daegu, Korea) 용액을 함유한 Dulbecco's Modified Eagle Medium (DMEM; WelGene Co.)을 이용하여 $5 \% \mathrm{CO}_{2}$ 가 공급되는 배양기(Thermo Fisher Scientific, Waltham, MA, USA)에서 $37^{\circ} \mathrm{C}$ 조건으로 배양하였다. RAW264.7 cells은 충분한 세포 를 얻기 위해 배양용 플라스크( $\left.T 75 \mathrm{~cm}^{2}\right)$ 에서 세포를 배양하 고, 약 $80 \%$ 밀집하면 부착된 세포를 떼어 낸 후 각 실험에 사용하였다.

\section{세포 생존율 측정}

RAW264.7 cells를 떼어 낸 후 성장배지에 세포수를 $1 \times 10^{4}$ cells/well로 조정하여 24-well plates에 세포를 분주하 여 24시간 동안 배양한 후 시료 처리를 하였다. 2시간 이상 기아상태를 유지시킨 후 시료를 우태야 혈청이 첨가하지 않은 성장배지로 희석하여 24시간 처리하여 세포 생존율을 알아보았다.

세포 생존율은 Chung 등(27)이 사용한 3-(4,5-dimethythiazol2-yl)-2,5-dipheyl terazolium bromid(MTT: Sigma-Aldrich Co., St Louis, MO, USA) 환원 방법을 이용하여 측정하였다. 즉, 각 well에 MTT 용액 $(5 \mathrm{mg} / \mathrm{mL})$ 을 성장배지의 10 분의 1 을 가해주고 다시 $37^{\circ} \mathrm{C}$ 에서 4 시간 더 배양하여 MTT를
환원시켜 생성된 formazon이 배지에 따라 나가지 않도록 배지를 조심스럽게 제거하였다. 남아있는 배지를 완전히 제거하기 위해 실온에서 30분간 방치한 후 dimethyl sulfoxide(DMSO; Sigma-Aldrich Co.)를 이용하여 용해시킨 시료를 $570 \mathrm{~nm}$ 에서 흡광도를 측정하였다. 흡광도 측정 시 공시료는 $\mathrm{DMSO}$ 로 하였고, 세포의 생존율은 아래와 같이 계산하였다.

$$
\text { 세포 생존율 }(\%)=\frac{\text { 시료 처리군의 흡광도 }}{\text { 대조군의 흡광도 }} \times
$$

\section{Nitric oxide와 cytokine 생성량 측정}

RAW264.7 cells를 떼어 낸 후 성장배지에 세포수를 $1 \times 10^{4}$ cells/well로 조정하여 24-well plates에 세포를 분주하 여 24시간 동안 배양한 후, 면역증진 효과를 알아보기 위해, RAW264.7 cells에 동결건조 분말 시료를 농도별로 각각 24시간 처리하였다. 면역증진 효과 실험에서 양성대조군은 시료 대신 $0.1 \mu \mathrm{g} / \mathrm{mL}$ lipopolysaccharide(LPS; Sigma-Aldrich Co.) 처리군이다.

세포배양액 $0.5 \mathrm{~mL}$ 에 동량의 Griess 시약( $1 \%$ sulfanilamide in $5 \%$ phosphoric acid와 $1 \%$ a-naphtylamide in $\mathrm{H}_{2} \mathrm{O}$ ) 0.5 $\mathrm{mL}$ 을 넣어 혼합하여 암실에서 10 분간 반응시킨 후, 540 $\mathrm{nm}$ 에서 흡광도를 측정하였다. Nitric oxide(NO)의 농도는 sodium nitrite $\left(\mathrm{NaNO}_{2}\right)$ 를 사용하여 얻은 검량선으로 산출하 였다(1).

세포배양액 중 TNF- $a, \mathrm{IL}-1 \beta$ 그리고 IL-6 농도는 ELISA kit(eBioscience Co., San Diego, CA, USA)을 이용하여 제조 사 지침에 따라 microplate reader(AMR-100, Allsheng Co., Ltd., Hangzhou, China)로 측정하였다.

\section{통계처리}

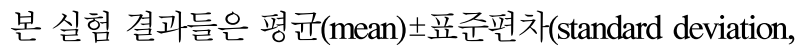
$\mathrm{SD}$ )로 표시하였고 실험군간 평균의 차이는 one-way ANOVA로 유의성을 확인한 후 Duncan's multiple range test를 이용하여 사후 검정하였으며 $\mathrm{p}<0.05$ 수준에서 유의 성의 여부를 검증하였다. 모든 통계 분석은 SPSS(statistical package for the social science) version 17.0 프로그램(SPSS Inc., Chicago, IL, USA)을 이용하여 분석하였다.

\section{결과 및 고찰}

RAW264.7 대식세포에서 12가지 식물 소재 추출물이 $\mathrm{NO}$ 생성에 미치는 영향

도라지, 더덕, 잔대, 옥수수수염, 당귀, 가시오가피, 황기, 천궁, 백출, 작약 그리고 마늘 물 추출물들 $(\mathrm{PG}, \mathrm{CL}, \mathrm{AT}$, $\mathrm{CS}, \mathrm{AG}, \mathrm{AS}, \mathrm{AM}, \mathrm{CO}, \mathrm{AR}, \mathrm{RR}, \mathrm{PR}, \mathrm{ALS})$ 의 면역증진 효과 
를 확인하기 위한 NO 생성에 대한 영향을 알아보았다(Fig. 1). 각각의 식물소재 추출물의 농도별 NO 생성을 확인한 결과 잔대와 마늘 추출물(AT, $\mathrm{ALS})$ 을 제외한 10 종류의 추 출물들은 농도 의존적으로 $\mathrm{NO}$ 생성량을 증가시켰다 (p<0.05). $100 \mu \mathrm{g} / \mathrm{mL}$ 추출물 처리농도에서 $\mathrm{NO}$ 생성량이 높은 순서는 옥수수수염 추출물(CS) > 도라지 추출물(PG) $=$ 가시오가피 추출물(AS) 순이었고, 이들 추출물들은 다른 추출물보다 현저하게 $\mathrm{NO}$ 생성량이 높았다 $(\mathrm{p}<0.05) . \mathrm{CS}, \mathrm{PG}$ 및 $\mathrm{AS}$ 를 제외한 다른 추출물들 처리 후 RAW264.7 대식세 포에 생성된 NO 생성량은 시료간의 유의적인 차이가 나타 나지 않았다 $(\mathrm{p}>0.05)$.

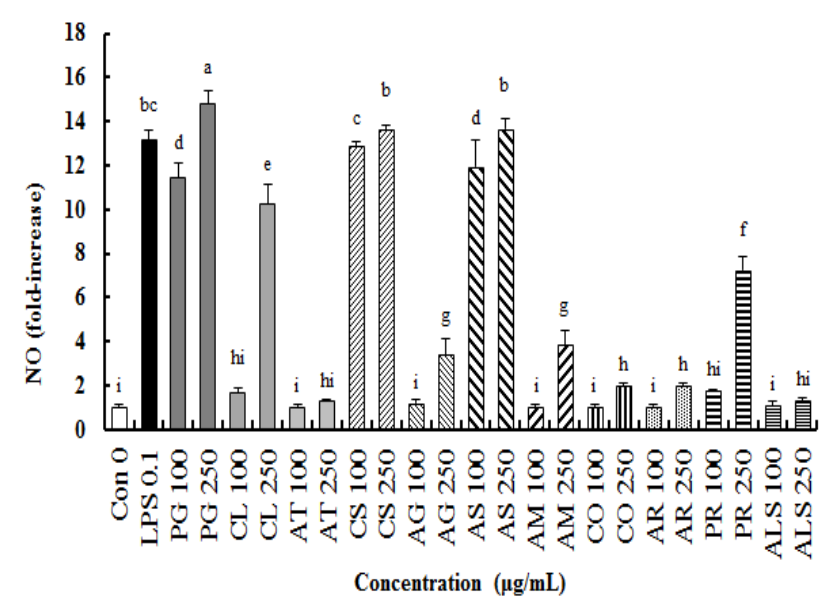

Fig. 1. Stimulatory effect of water extracts from Platycodon grandiflorum (PG), Codonopsis lanceolate (CL), corn silk (CS), Angelica gigas Nakai (AG), Acanthopanax senticosus (AS), Astragalus membranaceus (AM), Cnidium officinale (CO), Atractylodes macrocephala Koidzumi (AR), Rehmanniae Radix Preparat (RR), Allium sativum L (ALS), and sweet potato peel (SP) on the production of NO in RAW264.7 macrophages. LPS $(0.1 \mathrm{\mu g} / \mathrm{mL})$ was used as a positive control.

The values are expressed as mean $\pm \mathrm{SD}(\mathrm{n}=4)$; means with different letters significantly differ from each other $(\mathrm{p}<0.05)$, as determined by Duncan's multiple range test.

$250 \mu \mathrm{g} / \mathrm{mL}$ 추출물 처리농도에서 $\mathrm{NO}$ 생성량은 PG > $\mathrm{CS}=\mathrm{AS}>\mathrm{CL}>\mathrm{PR}>\mathrm{AG}=\mathrm{AM}>\mathrm{CO}=\mathrm{AR}$ 순으로 높았으며, $\mathrm{AT}$ 와 $\mathrm{ALS}$ 는 무처리군인 대조군과 비교하여 유 의적 차이가 없었다 $(\mathrm{p}>0.05)$.

과다한 $\mathrm{NO}$ 의 생성은 혈관확장이나 염증반응에 의한 조 직 손상을 일으켜 생체 내 유해한 작용을 나타낼 수 있으나 대식세포는 탐식 작용을 하는 동안 탐식된 병원균을 죽이기 위해 $\mathrm{NO}$ 를 생성하고, 생성된 $\mathrm{NO}$ 는 병원균을 죽이는 매개 체로서 중요한 역할을 하므로 적당량의 $\mathrm{NO}$ 생성 촉진은 면역 기능을 증진시킬 수 있는 지표로 사용될 수 있다(2). Kwon 등(28)의 연구결과에서 유근피 추출물 처리에 의한 $\mathrm{NO}$ 분비능이 증가하였는데, 이는 본 연구에서 도라지, 더 덕, 옥수수수염 및 가시오가피 추출물 처리에 의해 NO 생성 량이 현저하게 증가한 것과 유사한 결과였다.
도라지, 더덕, 옥수수수염, 가시오가피, 작약 및 고구마 껍질 추출물이 세포 생존율에 미치는 영향

$\mathrm{NO}$ 분비능 증가에 의해 면역 활성 증진 효과가 있을 것이라 생각되는 도라지, 더덕, 옥수수수염, 가시오가피, 작약 및 고구마껍질 추출물 $(\mathrm{PG}, \mathrm{CL}, \mathrm{CS}, \mathrm{AS}, \mathrm{PR}, \mathrm{SP})$ 의 세포 생존율에 미치는 영향을 알아보았다(Fig. 2). 이들 추 출물들을 처리한 결과 무처리군인 대조군(control)과 비교 하여 $\mathrm{PG}(100,250 \mu \mathrm{g} / \mathrm{mL}), \mathrm{CL}(100,250,500 \mu \mathrm{g} / \mathrm{mL})$ 그리고 $\mathrm{PR}(100,250,500 \mu \mathrm{g} / \mathrm{mL})$ 의 일정농도에서 RAW264.7 대식 세포 생존율이 유의적으로 증가하였다 $(\mathrm{p}<0.05)(\mathrm{Fig}$. 2). RAW264.7 대식세포에 PG $1000 \mu \mathrm{g} / \mathrm{mL}$ 와 CS $1000 \mu \mathrm{g} / \mathrm{mL}$ 를 처리한 군은 대조군과 비교하여 유의적으로 세포 생존율이 감소하여 $(\mathrm{p}<0.05)$ 도라지 그리고 옥수수수염 물 추출물은 고농도에서 세포독성이 있음을 알 수 있었다.

$\mathrm{Ryu}(29)$ 은 가시오가피 물 추출물이 마우스 비장세포 증 식능에 미치는 영향을 알아 본 결과 가시오가피 물 추출물 은 면역세포 증식능을 증가시켜 면역증진 효과가 있다고 보고 하였지만, 본 연구에서는 RAW264.7 대식세포에 가시 오가피 물 추출물을 처리한 결과 무처리군인 대조군과 비교 하여 유의적 차이가 없었다( $\mathrm{p}>0.05)$. 면역세포 증식률은 면 역 활성을 나타내는 바이오마커로 사용되고 있으며, 면역 증진 효과가 알려진 주박 다당류 처리에 의해 RAW264.7 대식세포의 증식률이 증가하였고(30), 본 연구에서도 PG, $\mathrm{CL}$ 그리고 PR 처리가 RAW264.7 대식세포 증식률을 증가 시키므로 면역 활성을 증진시키는 소재라는 것을 알 수 있었다.

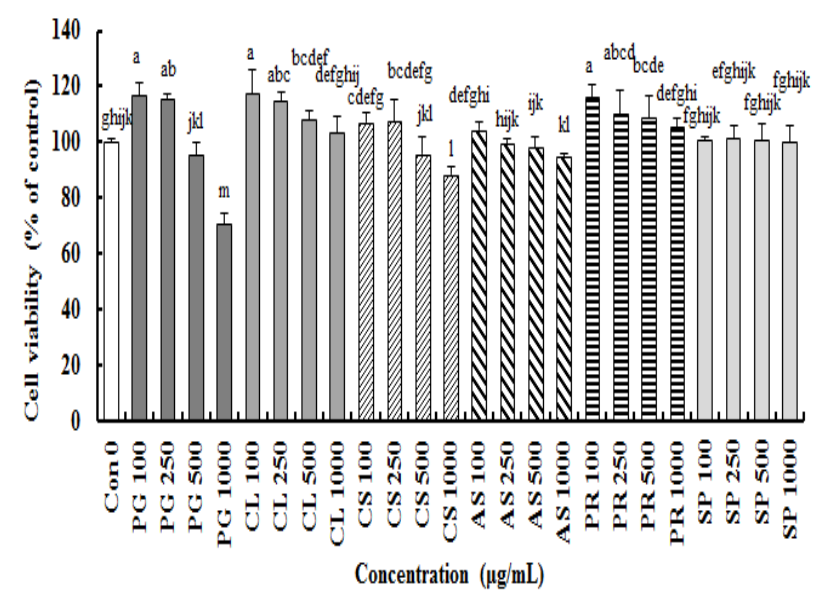

Fig. 2. Effect of water extracts from Platycodon grandiflorum (PG), Codonopsis lanceolate (CL), corn silk (CS), Acanthopanax senticosus (AS), Paeoniae radix (PR), and sweet potato peel (SP) on the cell viability. The RAW264.7 macrophages were treated with extract for $24 \mathrm{~h}$.

The values are expressed as mean $\pm \mathrm{SD}(\mathrm{n}=4)$; means with different letters significantly differ from each other $(\mathrm{p}<0.05)$, as determined by Duncan's multiple range test. 
RAW264.7 대식세포에서 도라지, 더덕, 옥수수수염 및 가시오가피 추출물이 TNF-a, IL-1 $\beta$ 그리고 IL-6 생성 에 미치는 영향

RWA264.7 대식세포에서 도라지, 더덕, 옥수수수염 및 가시오가피 추출물(PG, $\mathrm{CL}, \mathrm{CS}, \mathrm{AS})$ 이 TNF- $\mathrm{a}, \mathrm{IL}-1 \beta$ 그리 고 IL-6에 미치는 영향은 Fig. 3과 같다. PG, CL, CS 그리고 $\mathrm{AS}$ 처리한 후 세포 상등액에서 TNF- $a$ 함량이 농도 의존적 으로 증가하였고( $\mathrm{p}<0.05), 250 \mathrm{\mu g} / \mathrm{mL}$ 농도의 $\mathrm{PG}, \mathrm{CS}$ 및 $\mathrm{AS}$ 를 서로 비교했을 경우 유의적 차이가 없었지만( $\mathrm{p}>0.05)$, $\mathrm{CL}$ 처리군에 비하여 TNF- $a$ 함량이 유의적으로 높았다 $(\mathrm{p}<0.05) .500 \mu \mathrm{g} / \mathrm{mL}$ 농도의 $\mathrm{CL}, \mathrm{CS}$ 및 $\mathrm{AS}$ 를 서로 비교했을 경우 유의적 차이가 없었지만(p>0.05), PG 처리군보다는 $\mathrm{TNF}-a$ 함량이 유의적으로 낮았다(p<0.05). $500 \mu \mathrm{g} / \mathrm{mL}$ 시료 처리군 중에서 PG 처리에 의해 IL-1 $1 \beta$ 함량이 가장 높은 것은 $\mathrm{TNF}-a$ 와 유사한 경향이었고, $\mathrm{CS}$ 와 $\mathrm{AS}$ 처리군에서도 무처리군인 대조군과 비교하여 2 배 이상 IL-1 1 함량이 증가 하였고 CL도 1.5 배 이상 $\mathrm{IL}-1 \beta$ 함량이 증가하였다.

$\mathrm{IL}-6$ 함량은 100, 250 그리고 $500 \mu \mathrm{g} / \mathrm{mL}$ 시료 처리군 모두 PG 처리군이 $\mathrm{CL}, \mathrm{CS}$ 그리고 $\mathrm{AS}$ 처리군보다 $\mathrm{IL}-6$ 함량 이 더 높았다. $500 \mathrm{\mu g} / \mathrm{mL} \mathrm{CL}, \mathrm{CS}$ 그리고 $\mathrm{AS}$ 처리군은 대조 군과 비교하여 8배 이상 IL-6 함량이 높았다.

활성화된 대식세포가 분비하는 사이토카인은 광범위한 면역신호 전달인자이고 면역조절에 관여하는 대표적인 사 이토카인이 TNF- $a, \mathrm{IL}-1 \beta$ 그리고 IL-6로 대식세포에서 면 역증진 효과를 알아보는 중요한 바이오마커다(30).

유근피 추출물을 처리한 RAW264.7 대식세포에서 무처 리군인 대조군과 비교하여 TNF- $a$ 함량은 농도 의존적으로 증가하였으나, IL-1 $\beta$ 함량은 변화가 없었다(28). RAW264.7 대식세포에 주박에서 분리한 다당류를 처리한 후 TNF- $a$ 와 IL-6 함량이 증가되었다는 보고가 있다(30). 어성초 물 추출 물을 RAW264.7 대식세포에 처리했을 때 IL-1ß가 농도 의 존적으로 증가하였다고 하였다(31). 여러 연구에서 천연소 재의 면역증진 효과를 알아보기 위해 시료 처리 후 TNF-a, $\mathrm{IL}-1 \beta$ 그리고 IL-6 함량 증가를 확인하였다(28,30,31). 따라 서 천연소재를 처리했을 때 대식세포에서 TNF- $a, \mathrm{IL}-1 \beta$ 그리고 IL-6 함량이 증가하면 면역증진 효과를 가진 소재인 것으로 추정한다(30). 본 연구에서도 도라지, 더덕, 옥수수 수염 및 가시오가피 물 추출물이 RAW264.7 대식세포에서 TNF-a, IL-1 $\beta$ 그리고 IL-6 함량을 증가시켰으므로 면역증 진 효과를 가진 소재라는 것을 확인할 수 있었다.

RAW264.7 대식세포에서 고구마껍질 추출물이 NO, TNF-a, IL-1 $\beta$ 그리고 IL-6 생성에 미치는 영향

고구마껍질 추출물(SP) 처리가 RAW264.7 대식세포에 서 NO 및 pro-inflammatory cytokine(TNF- $a$, IL-1 $1 \beta$ 그리고 IL-6) 분비에 미치는 영향을 Fig 4에 나타내었다. RAW264.7 대식세포에서 양성 대조군인 $0.1 \mathrm{\mu g} / \mathrm{mL}$ LPS 처리군이 SP

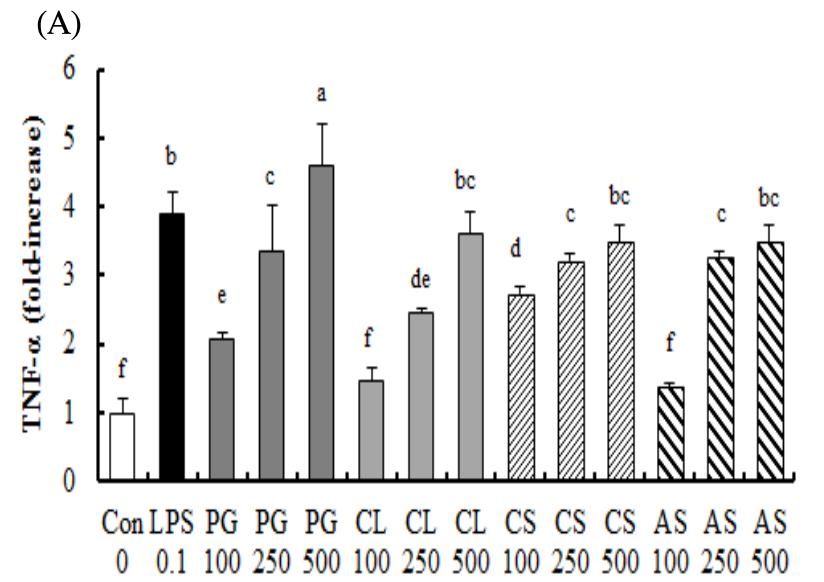

Concentration $(\mu \mathrm{g} / \mathrm{mL})$

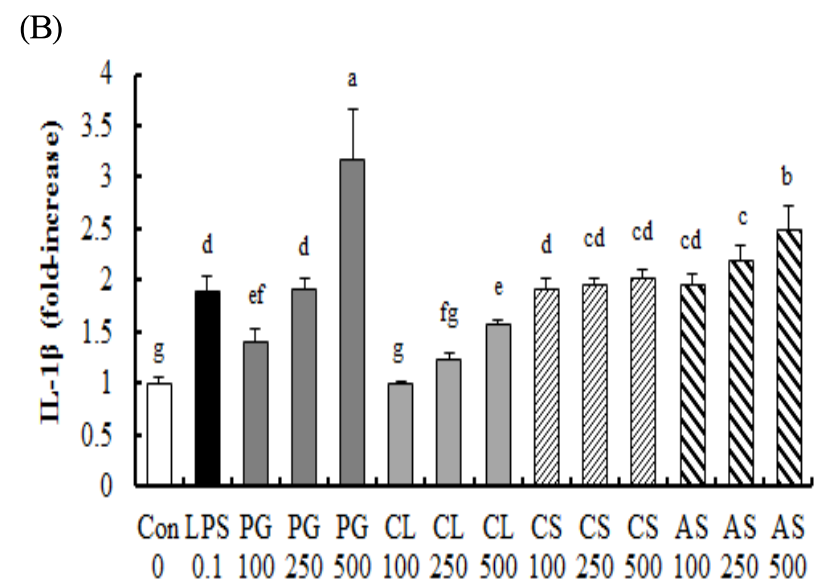

Concentration $(\mu \mathrm{g} / \mathrm{mL})$

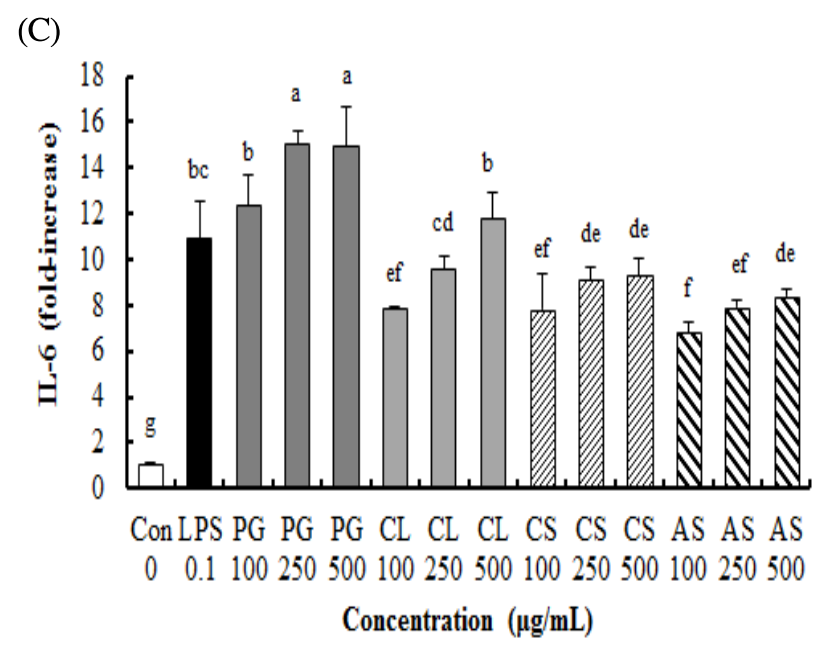

Fig. 3. Stimulatory effect of water extracts from Platycodon grandiflorum (PG), Codonopsis lanceolate (CL), corn silk (CS), and Acanthopanax senticosus (AS) on the production of TNF-a (A), IL-1 $\beta$ (B) and IL-6 (C) in RAW264.7 macrophages. LPS $(0.1 \mathrm{\mu g} / \mathrm{mL})$ was used as a positive control.

The values are expressed as mean $\pm \mathrm{SD}(\mathrm{n}=4)$; means with different letters significantly differ from each other $(p<0.05)$, as determined by Duncan's multiple range test. 
(A)

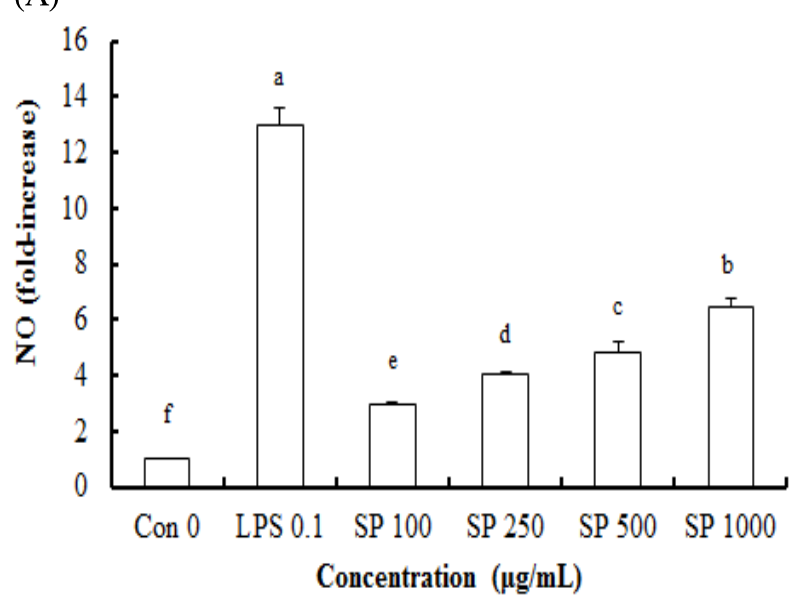

(C)

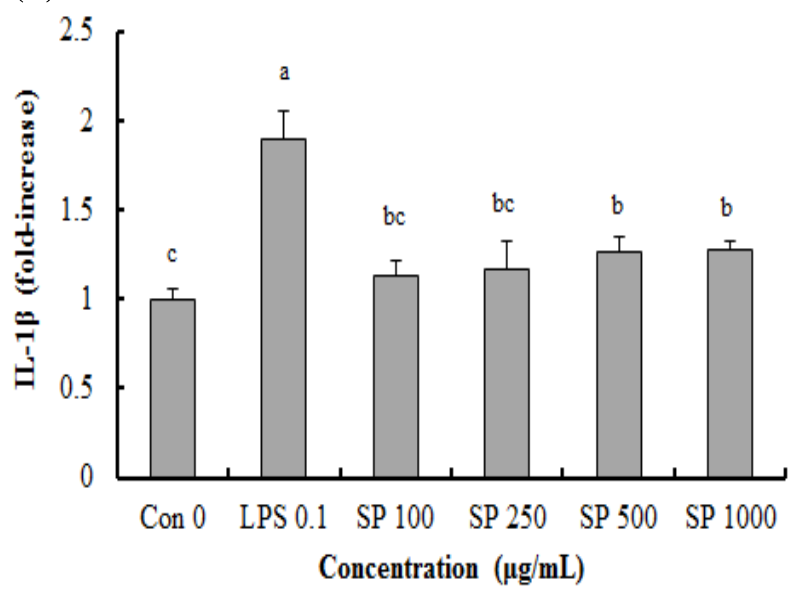

(B)

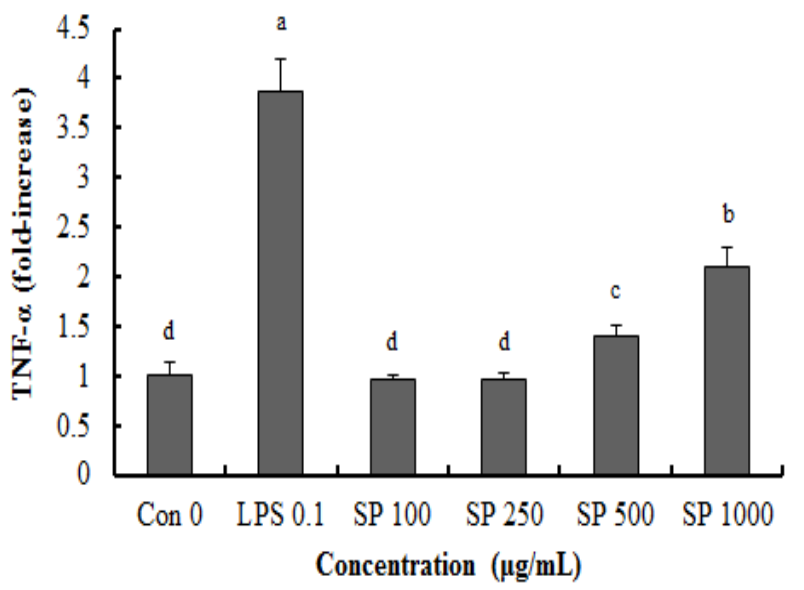

(D)

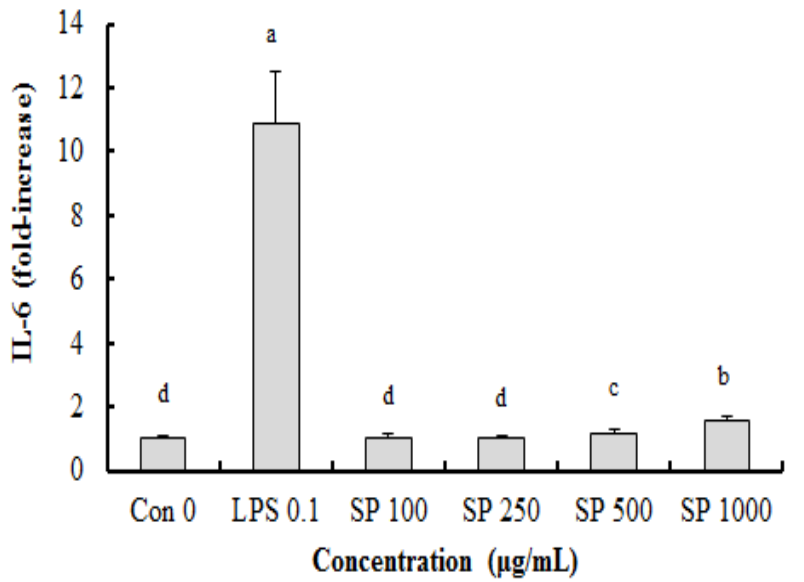

Fig. 4. Stimulatory effect of water extracts from sweet potato peel (SP) on the production of NO (A), TNF- $a$ (B), IL-1ß (C) and IL-6 (D) in RAW264.7 macrophages.

LPS $(0.1 \mu \mathrm{g} / \mathrm{mL})$ was used as a positive control. The values are expressed as mean $\pm \mathrm{SD}(\mathrm{n}=4)$; means with different letters significantly differ from each other ( $<<0.05)$, as determined by Duncan's multiple range test.

처리군보다 NO, TNF- $a, \mathrm{IL}-1 \beta$ 그리고 IL-6 함량이 높았으 며, SP 처리에 의해 NO, TNF-a, IL-1 $\beta$ 그리고 IL-6 함량이 농도 의존적으로 증가하였다. 100 및 $250 \mu \mathrm{g} / \mathrm{mL} \mathrm{SP}$ 처리에 의해 NO 함량은 대조군과 비교하여 유의적으로 증가하였 다(p<0.05). RAW264.7 대식세포에서 TNF- $a, \mathrm{IL}-1 \beta$ 그리고 $\mathrm{IL}-6$ 는 함량은 100 및 $250 \mu \mathrm{g} / \mathrm{mL}$ SP 처리에 의해 변화가 없었으나 500과 $1000 \mathrm{\mu g} / \mathrm{mL} \mathrm{SP}$ 처리에 의해 유의적으로 증가하였다(p<0.05). 고구마껍질은 농도 의존적으로 면역 활성이 증진되었다. 도라지, 더덕 그리고 옥수수수염과 비 교했을 때 고구마껍질의 면역활성 증진 효과는 낮았다.

\section{RAW264.7 대식세포에서 고구마껍질을 주원료로 한 식 물 혼합물이 NO 생성에 미치는 영향}

본 연구의 목적은 폐기되고 있는 고구마껍질을 활용하는 것이므로 고구마껍질 포함 4 개의 천연소재를 이용하여 5 종 류의 배합비를 만들었고(Table 1; Mixtures 1-5), 5종류 배합
비의 NO 생성량에 미치는 영향을 조사하였다(Fig. 5).

RAW264.7 대식세포에 Mixture 1, Mixture 2 그리고 Mixture 3을 처리한 결과 농도 의존적으로 NO 함량이 증가 하였고 NO 생성량이 Mixture 4와 Mixture 5보다 높았다 (Fig. 5).

RAW264.7 대식세포에서 도라지, 더덕, 옥수수수염, 고구마껍질 및 이들의 혼합물이 NO, TNF- $a, I L-1 \beta$ 그 리고 IL-6 생성에 미치는 영향

5 종류의 고구마껍질을 주원료로 한 식물 혼합물 중에 관능검사 결과는 Mix3가 가장 점수가 높았다(data not shown). 맛과 NO 함량 증진 효과가 5종류 혼합물 중에서 뛰어난 Mix1과 Mix3, 맛과 NO 함량 증진 효과는 Mix1과 Mix3보다 낮지만 폐기되고 있는 고구마껍질 함량이 가장 높은 Mix5를 계속되는 실험을 위해 선택하였다. 즉, 이들 혼합물에 함유된 단일 추출물들과 혼합물들(Mix1, Mix3, 


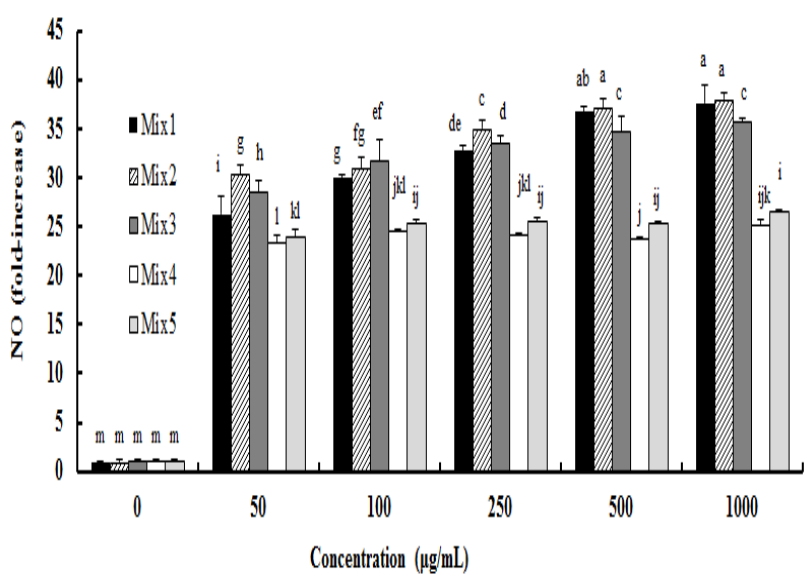

Fig. 5. Stimulatory effect of extracts from the plant mixtures based on sweet potato peel on the production of NO in RAW264.7 macrophages.

The values are expressed as mean $\pm S D(n=4)$; means with different letters significantly differ from each other $(\mathrm{p}<0.05)$, as determined by Duncan's multiple range test. The explanation of mixture 1 (Mix 1), Mix 2, Mix 3, Mix 4, and Mix 5 are provided in Table 1.
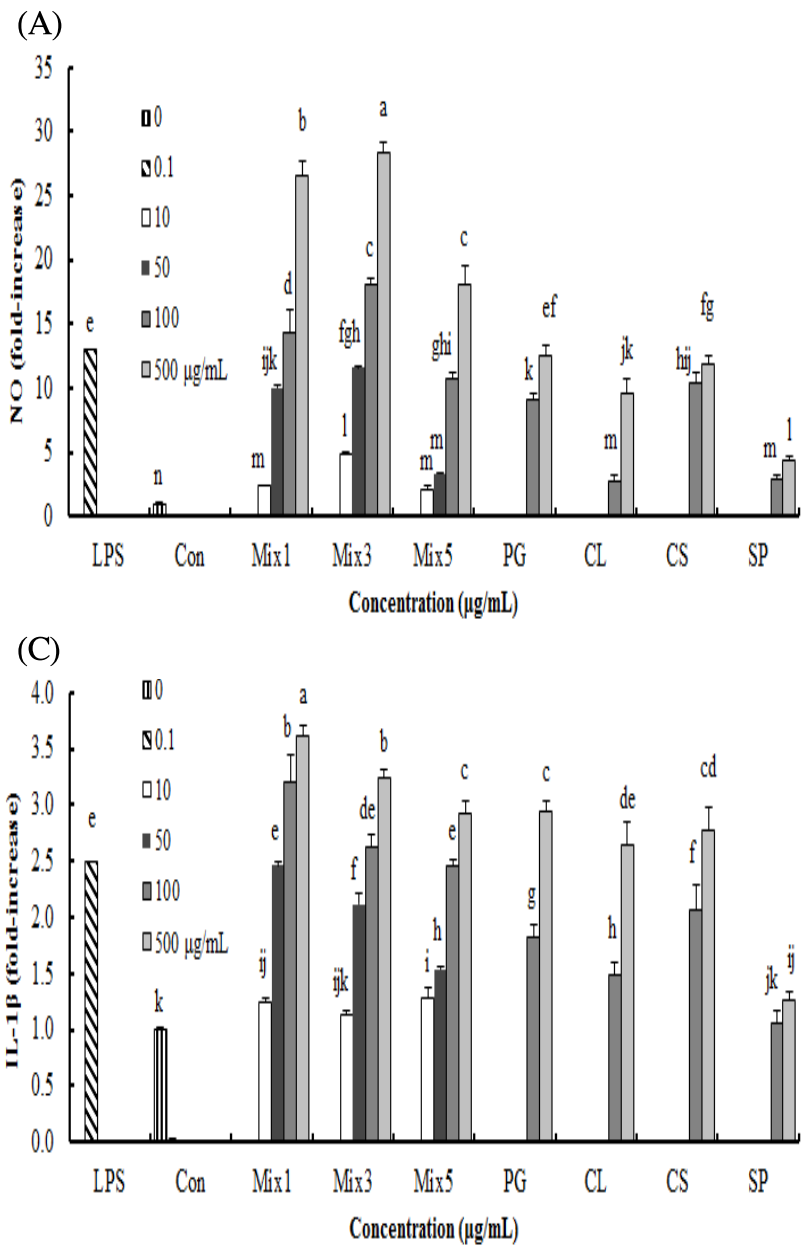

Mix5)의 면역활성을 비교하였다.

Mix1, Mix3, Mix5 및 이들 혼합물에 함유된 도라지, 더덕, 옥수수수염 및 고구마껍질 추출물 $(\mathrm{PG}, \mathrm{CL}, \mathrm{CS}, \mathrm{SP})$ 를 RAW264.7 대식세포에 처리한 결과 면역활성에 미치는 영 향을 알아본 결과는 Fig. 5와 같다.

RAW264.7 대식세포에서 고구마껍질을 주원료로 한 식 물 혼합물(Mix1, Mix3, Mix5)은 NO, TNF- $a, \mathrm{IL}-1 \beta$ 그리고 IL-6 모두 농도 의존적으로 증가하였고, 모든 농도에서 고 구마껍질 추출물 $(\mathrm{SP})$ 보다 면역 활성이 높았다 $(\mathrm{p}<0.05)$.

RAW264.7 대식세포에 Mix1과 Mix3을 처리한 결과 이 들 혼합물에 함유된 도라지, 더덕, 옥수수수염 및 고구마껍 질보다 NO 함량은 높았고 TNF-a, IL-1 그리고 IL-6은 높거 나 유사하였다. 따라서 면역 활성이 높으면서, 맛도 좋고 고구마껍질을 함유 비율도 높아 폐기되고 있는 고구마껍질 의 활용도가 높은 $\mathrm{Mix} 3$ 을 제품개발을 위한 최적 배합비로 결정하였다.

(B)

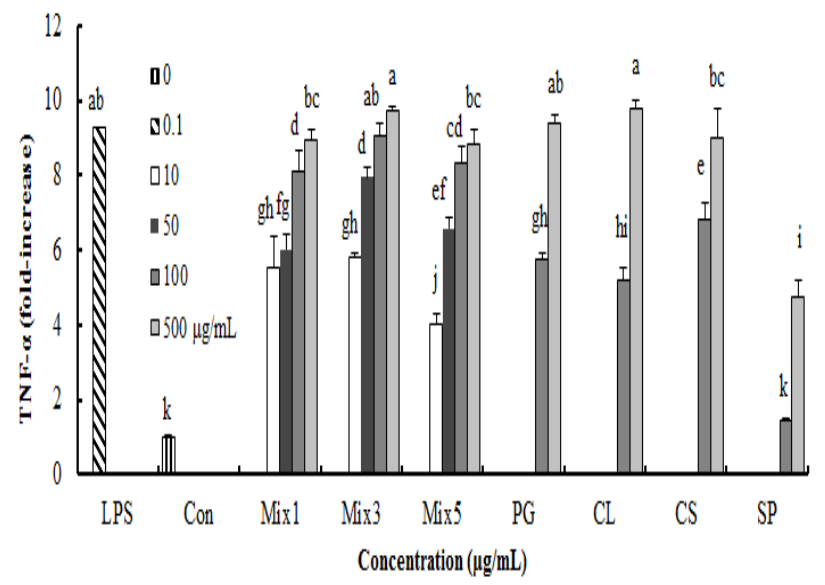

(D)

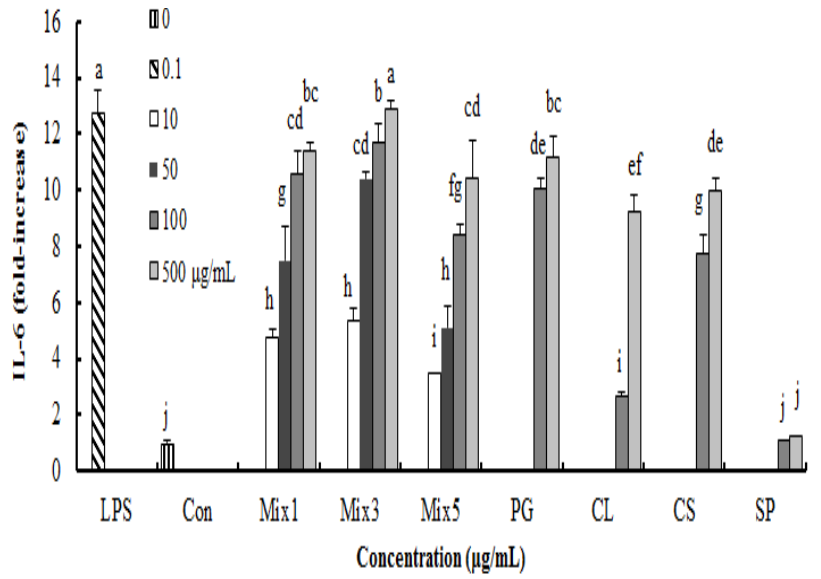

Fig. 6. Stimulatory effect of water extracts from Platycodon grandiflorum (PG), Codonopsis lanceolate (CL), corn silk (CS), sweet potato peel (SP) and their mixture based on sweet potato peel on the production of NO, TNF- $a$, IL-1 $\beta$ and IL-6 in RAW264.7 macrophages. LPS $(0.1 \mathrm{\mu g} / \mathrm{mL})$ was used as a positive control.

The values are expressed as mean $\pm \mathrm{SD}(\mathrm{n}=4)$; means with different letters significantly differ from each other ( $\mathrm{p}<0.05$ ), as determined by Duncan's multiple range test. The explanation of mixture 1 (Mix 1), Mix 3, and Mix 5 are provided in Table 1. 
더덕 물 추출물이 마우스 복강 대식세포를 활성화 시켜 IL-6 분비를 촉진시켰고 더덕 물 추출물을 마우스에 투여하 였을 때와 면역세포에 처리했을 경우 TNF-a 생성량이 증가 한다는 보고들이 있고(12,13,32), 더덕 및 가시오가피 물 추출물 처리가 면역세포에서 TNF- $\mathrm{a}$ 생성량을 유의적으로 증가시켰다는 보고가 있다 $(29,32)$. 본 연구 결과에서도 더 덕 및 가시오가피 물 추출물 처리가 면역세포에서 면역관련 사이토카인 생성량을 증가시켰다.

본 연구팀은 이들 최적 배합비를 이용한 면역증진 효과 가 있는 가공식품을 산학협력을 통해 현재 개발 중에 있으 며, 향후 개발된 제품들도 면역증진 효과를 나타내는지 조 사할 계획이다. 또한 이들 Mix3 및 개발된 제품의 면역력 증진효과는 동물실험에서 RAW264.7 대식세포와 유사한 결과들을 얻을 수 있는지 알아볼 것이다. 따라서 본 연구는 폐기되고 있는 고구마껍질을 활용한 면역증진 효과가 우수 한 가격 경쟁력이 있는 천연소재 최적 배합비를 가진 식물 혼합물을 개발한 연구결과이므로 이들 식물혼합물을 이용 한 면역력 증진 효과를 가진 다양한 제품 개발 등 산업, 경제적으로 활용가치가 높을 것으로 기대된다.

\section{요 약}

본 연구는 RAW264.7 대식세포에서 고구마껍질을 주원 료로 하고 도라지, 더덕 그리고 옥수수수염을 함유한 식물 혼합물의 면역활성 증진효과를 연구하였다. RAW264.7 대 식세포에서 NO 생성량으로 12 가지 식물 추출물들의 면역 증진 효과를 알아보았다. RAW264.7 대식세포에서 도라지, 더덕 및 옥수수수염 추출물들(PG, CL, CS)처리에 의한 NO 생성량이 다른 식물 추출물들 처리에 의해서 보다 유의적으 로 높았다. RAW264.7 대식세포에서 $\mathrm{PG}, \mathrm{CL}, \mathrm{CS}$ 그리고 고구마껍질 추출물(SP)에 의한 세포독성, NO 생성량 및 사이토카인 생성량을 측정하였다. $\mathrm{PG}, \mathrm{CL}$ 또는 $\mathrm{CS}$ 를 처리 한 RAW264.7 대식세포에서 TNF-a, IL-1ß 그리고 IL-6 생 성량이 SP를 처리한 군보다 현저하게 높았다. 도라지, 더덕, 옥수수수염 그리고 고구마껍질을 1:1:0.5:3(w/w) 비율로 섞 어 혼합물을 만들었다. RAW264.7 대식세포에서 혼합물로 부터 얻은 추출물의 면역증진 효과는 $\mathrm{SP}$ 보다 높았고 $\mathrm{PG}$, $\mathrm{CL}$ 그리고 $\mathrm{CS}$ 각각 보다는 유사하거나 높았다. 개발된 혼 합물로부터 얻은 추출물은 면역 활성을 향상시킬 수 있는 기능성 식품 소재 개발을 위한 잠재적 후보일 것이다

\section{감사의 글}

본 연구는 2018년도 중소벤처기업부의 산학연협력 기술 개발사업 지원에 의한 연구임 (NO. S2661298).

\section{References}

1. Kim MH (2018) Comparison of chronic disease risk by egg consumption in Korean adult women based on the 2013 Korea national health and nutrition examination survey. Korean J Food Nutr, 31, 33-42

2. Jung JI, Kim JM, Kim HS, Kim HS, Kim EJ (2019) Immunostimulatory effect of wild-cultivated ginseng extract via the increase in phagocytosis and cytokine secretions in Raw264.7 macrophages. J Korean Soc Food Sci Nutr, 48, 686-691

3. Kim HW, Kim KY, Lee SY, Kim GY, Jeon BG, Cho SI, Jeong HW (2008) Immuno-stimulating effects of Oga-Power (OP) containing extract of Acanthopanax sessiliflorus on immune cells in mice. Kor J Herbology, 23, 141-147

4. Kim YE, Lee JH, Sung NY, Ahn DH, Byun EH (2017) A comparative study of the immuno-modulatory activities of ethanol extracts and crude polysaccharide fractions from Annona muricata L. Korean J Food Sci Technol, 49, 453-458

5. Bendich A, Olson JA (1989) Biological actions of carotenoids. FASEB J, 3, 1927-1932

6. Kim CH, Jung BY, Jung SK, Lee CH, Lee HS, Kim BH, Kim SK (2010) Evaluation of antioxidant activity of Platycodon grandiflorum J Environ Toxicol, 25, 85-94

7. Tran QL, Adnyana IK, Tezuka Y, Harimaya Y, Saiki I, Kurashige Y, Tran QK. Kadota S (2002) Hepatoprotective effect of majonoside R2, the major saponin from Vietnamese ginseng (Panax vietnamensis). Planta Med, 68, 402-406

8. Rao AV, Sung MK (1995) Saponins as anticarcinogens. J Nutr, 125, 717-724

9. OzakiI Y (1995) Studies on antiinflammatory effect of Japanese oriental medicines (Kampo Medicines) used to treat inflammatory diseases. Biol Pharm Bull, 18, 559-562

10. Choi MS, Choi PS (1999) Plant regeneration and saponin contents in Codonopsis lanceolata L. Korean J Medicinal Crop Sci, 7, 275-281

11. Kang YH (2009) Phenolic compounds and antioxidant activity in cell wall materials from Deodeok (Codonopsis lanceolata). Korean J Food Sci Technol, 41, 345-349

12. Han EG, Cho SY (1997) Effects of Codonopsis lanceolata water extract on the activities of antioxidative enzymes in carbon tetrachloride treated rats. J Korean Soc Food Sci Nutr, 26, 1181-1186

13. Han EG, Sung IS, Moon HG, Cho SY (1998) Effects 
of Codonopsis lanceolata water extract on the levels of lipid in rats fed high fat diet. J Korean Soc Food Sci Nutr, 27, 940-944

14. Maeng YS, Park HK (1991) Antioxidant activity of ethanol extract from Dodok (Codonopsis lanceolata). Korean J Food Sci Technol, 23, 311-316

15. Ryu HS (2008) Effects of Codonopsis lancelata extracts on mouse immune cell activation. J Korean Soc Food Sci Nutr, 21, 263-268

16. Lim SD, Seung KS, Kim KS, Han DU (2007) Effects of fermented milk with hot water extract from Acanthopanax senticosus and Codonopsis lanceolata on the immune status of mouse. Korean J Food Sci Technol, 39, 323-329

17. Won HR, Oh HS (2007) Antioxidative activity and lipid composition from different part and supplement of Codonopsis lanceolata in rat. J Korean Soc Food Sci Nutr, 36, 1128-1133

18. Lee JH, Kim HJ, Kim MJ, Jung GH, Lee BW, Lee BK, Woo KS (2017) Quality and antioxidant characteristics of roasted maize tea according to cultivation period and variety. J Korean Soc Food Sci Nutr, 46, 1316-1326

19. Choi HJ, Kim SL, Kang HJ, Kim MH, Kim WK (2019) The Effect of saccharin on the gene expression of NF- $\mathrm{kB}$ and inflammatory cytokines in LPS-stimulated SW480 colon cancer cells. J Korean Diet Assoc, 25, 217-228

20. Hasanudin K, Hashim P, Mustafa S (2012) Corn silk (Stigma maydis) in healthcare: a phytochemical and pharmacological review. Molecules, 17, 9697-9715

21. Grases F, March JG, Ramis M, Costa Bauza A (1993) The influence of Zea mays on urinary risk factors for kidney stones in rats. Phytother Res, 7, 146-149

22. Min OJ, Sharma BR, Park CM, Rhyu DY (2010) Effect of myadis stigma water extract on adipogenesis and blood glucose in 3T3-L1 adipocytes and $\mathrm{db} / \mathrm{db}$ mice. Korean J Pharmacogn, 42, 201-208

23. Byrne PF, McMullen MD, Snook ME, Musket TA, Theuri JM, Widstrom NW, Wiseman BR, Coe EH (1996) Quantitative trait loci and metabolic pathways: genetic control of the concentration of maysin, a corn earworm resistance factor, in maize silks. Proc Natl Acad Sci USA, 93, $8820-8825$
24. Lee GH, Kwon BK, Yim SY, Oh MJ (2000) Phenolic compounds in sweet potatoes and their antioxidative activity. Korean J Food Preserv, 7, 331-336

25. Bufalo MC, Sforcin JM (2015) The modulatory effects of caffeic acid on human monocytes and its involvement in propolis action. J Pharm Pharmacol, 67, 740-745

26. Park JH, Lee JK, Kim HS, Chung ST, Eom JH, Kim KA, Chung SJ, Paik SY, Oh HY (2004) Immunomodulatory effect of caffeic acid phenethyl ester in Balb/c mice. Int Immunopharmacol, 4, 429-436

27. Chung MJ, Lee SH, Park YI, Lee JS, Kwon KH (2016) Neuroprotective effects of phytosterols and flavonoids from Cirsium setidens and Aster scaber in human brain neuroblastoma SK-N-SH cells. Life Sci, 148, 173-182

28. Kwon DH, Kang HJ, Choi YH, Chung KT, Lee JH, Kang KH, Hyun SK, Kim BW, Hwang HJ (2016) Immunomodulatory activity of water extract of Ulmus macrocarpa in macrophages. J Life Sci, 26, 50-58

29. Ryu HS (2015) Enhancing effect of Acanthopanax senticosus extract on mouse spleen and macrophage cells activation. Korean J Food Nutr, 28, 253-257

30. Park WY, Sung NY, Byun EH, Oh KH, Byun MW, Yoo YC (2015) Immuno-modulatory activities of polysaccharides separated from Jubak in macrophage cells. J Korean Soc Food Sci Nutr, 44, 1079-1083

31. Kim JH, Kim YS, Lim EM (2012) Immune enhancing effect of Houttuniae Herba on mouse macrophage. J Orient Obstet Gynecol, 25, 12-22

32. Kim EH, Gwak JY, Chung MJ (2018) Immunomodulatory activity of Platycodon grandiflorum, Codonopsis lanceolata, and Adenophora triphylla extract in macrophage cells. J Korean Soc Food Sci Nutr, 47, 1069-1075 